Л. Ф. Украӥнець

\title{
АСОЦІАТИВНА ІНФОРМАТИВНІСТЬ ФОНЕТИЧНИХ ОДИНИЦЬ У ПОЕТИЧНОМУ ДИСКУРСІ
}

Українець Л. Ф. Асоціативна інформативність фонетичних одиниць у поетичному дискурсі.

У статті розглядається здатність звуків формувати в українській поетичній мові семантичні й прагматичні домінанти як елемент естетичного відображення явищ об'єктивної дійсності. Інтерпретацію асоціативної інформативності вокальних і консонантних одиниць та їхніх диференційних ознак здійснено в контексті відображення індивідуальних та національних параметрів мовної картини світу.

Ключові слова: український поетичний дискурс, асоціація, конотація, фонетичні одиниці, голосні, приголосні.

Украинец Л. Ф. Ассоциативная информативность фонетических единиц в поэтическом дискурсе.

В статье рассматривается способность звуков формировать в украинском поэтическом языке семантические и прагматические доминанты как элемент С Л. Ф. Українець, 2015. 
эстетического отображения явлений объективной действительности. Интерпретацию ассоциативной информативности вокальных и консонантных единиц, а также их дифференциальных признаков осуществлено в контексте отображения индивидуальных и национальных параметров языковой картины мира.

Ключевые слова: украинский поэтический дискурс, ассоциация, коннотация, фонетические единицы, гласные, согласные.

Ukrainets L. F. Associative information value of phonetic units in poetic discourse.

This article deals with sounds' ability to generate semantic and pragmatic dominants as an element of the aesthetic reflection of objective reality phenomena in Ukrainian poetic language. The interpretation of associative information value of vocal and consonant units, as well as their distinctive features has implemented in the context of individual and national characteristics of world's linguistic picture.

Key words: Ukrainian poetic discourse, association, connotation, phonetic units, vowels, consonants.

Увага до семіотичних властивостей фонетичних одиниць як носіїв прагматичної інформації в сучасній лінгвістиці - це результат системних спостережень ізоморфізму плану змісту та плану вираження, що пов'язані в славістиці з основоположними науковими концепціями Л. Сльмслева [8], Є. Куриловича [13], Е. Макаєва [14], Т. Булигіної [5], К. Долініна [7], А. Кондратова [10], а в україністиці - 3 теоретичними здобутками М. Кочергана [12], О. Мельничука [1], Т. Радзієвської [15], О. Селіванової [16], С. Семчинського [17] та ін. Об'єктивація структурного паралелізму між звуковою та змістовою (семантичною) стороною мови в сучасній лінгвістиці отримала назву «семіологічної релевантності звука» $[3$, с. 8] i співвідноситься з поняттям «значення», яке, по суті, можуть продукувати й фонетичні одиниці незалежно від їхніх диференційних (інтегральних) характеристик. I хоч у класичному мовознавстві вже традиційним стало твердження, згідно з яким звуки є лише елементом плану вираження лінгвістичного знака, однак, на думку Л. Зіндера, це не означає, що вони не корелюють зі змістовими домінантами, адже такий зв'язок (хоч і непрямий) існує: «Саме можливість виступати в ролі смислової одиниці й виділяє окремий звук у потоці мовлення» [9, с. 39]. Цим науковим постулатом учений розвинув і модифікував ідею Л. Щерби про потенційний зв'язок фонетичних одиниць зі значенням як основу членування мовлення на окремі артикуляційно-акустичні сегменти (звукотипи), підтвердивши воднораз і справедливість теорії ієрархії рівнів Е. Бенвеніста - виданого французького дослідника лексичної і граматичної семантики - про набуття змісту відповідною лінгвістичною одиницею лише у вищому для неї рівні мови. У цьому зв'язку важливо «при зіставленні звукових і семантичних 
одиниць різного ступеня складності <..> орієнтуватися на план вираження, намагаючись виокремити в плані змісту аналоги фонологічних одиниць, оскільки саме фонологія оперує завершеною системою понять, що лежать в основі концепції структурної упорядкованості звукового плану мови $<\ldots>>$ » $[5$, с. 76$]$.

Позбавлені денотативно-референтної матеріалізації, у різних дискурсивних площинах звуки здатні породжувати імпліцитну інформацію у вигляді асоціативно-конотаційних нашарувань, які семасіологи термінологічно окреслюють із позицій стилістики («стилістичне співзначення» [4]), психологічного антропоцентризму («семантичні асоціації» [2]), структури номінативного значення лексичних одиниць («приховані семи» [6]) або комунікативної прагматики («емотив» [19]).

Винятково яскраві фонетичні конотації в поезії, експресивноемоційна вартість якої підпорядкована аудіально-візуальній синестезії, що детермінує не лише символічність звуків, але й глибинні мікросемантичні парадигми формування вербальних архетипів, завдяки яким українська поетична мова виявляє риси сугестивного впливу. Оскільки характеристика імпліцитних рис фонетичної системи як засобу створення естетичної реальності в україністиці ще не має свого належного теоретичного обгрунтування, то об'єктом для аналізу було обрано емоційну інформативність голосних і приголосних в українському поетичному дискурсі, де форма ментальної комунікації найповніше підпорядкована мелодійному суголоссю звукового континууму.

Мета статті - охарактеризувати емоційно-експресивну вартість фонетичних одиниць як ознаку самобутності звукової системи українського поетичного дискурсу.

Матеріалом для спостереження обрана українська поетична мова XX-XXI ст., лірична образність якої вражає асоціативною інформативністю звукових жестів. Семантико-прагматичні метаморфози такої мови $\epsilon$ наслідком авторської версифікації, архітектоніка якої детермінована повтором голосних і приголосних, що акцентують увагу на синтагматиці фонетичних одиниць як основі реальних і потенційних змістових парадигм поетичного моделювання естетичної інформації.

У системі традиційних фоностилістичних особливостей поетичного дискурсу перебуває, природно, анафоричний (анафора) та епіфоричний (епіфора) звукопис, здатний синхронізувати семантичні й емоційні компоненти такої архітектонічної структури. Приміром, однакові вокальні сегменти на початку суміжних рядків важливі як елементи оригінальної стилістичної фігури полісиндетона, що привертає увагу С Л. Ф. Українець, 2015. 
додатковим емоційним напруженням унаслідок психологічного нагнітання: I все на світі треба пережити. I кожен фініш - це, по суті, старт. I наперед не треба ворожстии, $\boldsymbol{i}$ за минулим плакати не варт (Л. Костенко «Пісенька 3 варіаціями»).

Фонетична епіфора (особливо на тлі брутального мовлення зі стилістично мотивованими неологізмами) часто змушує сконцентрувати увагу на суто авторській домінанті світобачення, навіть якщо це асоціативноіронічне позиціонування квінтесенції буття: $\boldsymbol{Я}$ повний вигуків $i$ захвату дослізного. Як це весело - гладити кобилячу пику. $\boldsymbol{Я}$ паяи безреготний, натхненний дивовижно, $\boldsymbol{Я}$ - директор циику (М. Семенко «Цирк»).

Інтенційна інформативність звукового інструментування епіфоричного типу підпорядкована передовсім версифікаційним приписам, де ритм є визначальною стратегією версифікаційного мовотворення, хоч конотаційний спектр фонетичних одиниць можливий - і навіть закономірний! - у контексті авторських лексико-семантичних парадигм: < ..> I недоспівані пісні В невідомій далечині, - Немов у сні. $<\ldots>$ I невловиме слово «ні» Немов у сні (Б. Лепкий «Тиха ніч»).

Крім класично запрограмованих звукових комплексів, поетична мова часто послуговується оказіонально локалізованими звуковими жестами, що корелюють зі стихією емоцій: Знову біблія літа розкрила Сторінки заколосених піль. Легкий вітер напружує крила Гнати леготом золото хвиль (Є. Маланюк «Євангелія піль»).

Інтонаційно-звукова канва такого поетичного зразка підпорядкована асоціативній інтерпретації артикуляційно-акустичних ознак бокових [л], [л'] як інтенційно приємних звукових стимулів, що апелюють лише до позитивних емоцій, тому регульовані, природно, естетикою звучання однією з найважливіших облігаторних функцій поетичного дискурсу. Мав рацію В. Коптілов, коли зауважував, що «легка для вимови (і через те асоційована в нашій свідомості з поняттям легкості взагалі) фонема л < ..> увиразнює змальовану автором картину» [11, с. 218].

Конотацію приємного, красивого звучання - суголосся мелодійного й неповторного - створює й вокальна гармонія, коли мелодія слова сформована домінувальним голосним, нагадуючи вивірений тисячоліттям повноголосий варіант моделювання структури слова: Горем ї̈ не оковано, В серие не вкралася лють. Співом, ласкавою мовою Всяк обдаровує люд (Б. Олійник «Благословіння»).

Майстерно користуються митці й звуковим підхопленням як різновидом повтору - джерелом емоційної фонетичної конотації: I хоч січень січе, а мені за плечем Журавлі журавлять. I вино вже давно 
хмільно так хмелиться (Б. Олійник «Мати сіяла сон»).

Інформативність такого «звукопису локальних масштабів» [18, с. 15] на рівні породження конотацій можлива, безперечно, лише за умови, якщо фонетичні одиниці корелюють 3 одиницями лексико-семантичного та граматичного рівнів - лексемами, морфемами, синтаксемами - i спрямовані на відтворення національних пріоритетів мовної картини світу.

\section{Література}

1. Академік Олександр Савич Мельничук і сучасне мовознавство : [3б. наук. праць до 90-річчя з дня народження]. - К. : ВД Дмитра Бураго, 2012. - 280 с.

2. Апресян Ю. Д. Лексическая семантика. Синонимические средства языка / Ю. Д. Апресян. - М. : Наука, 1974. - 368 с.

3. Ахманова О.С. Лингвистическое значение и его разновидности / О. С. Ахманова // Проблема значения в лингвистике и логике : [тезисы докладов]. М. : Изд-во Моск. ун-та, 1963. - С. 7-10.

4. Балли Ш. Французская стилистика / Ш. Балли ; [пер. с фр. К. А. Долинина]. М. : Изд-во иностр. лит., 1961. -393 с.

5. Булыгина Т. В. О некоторых аналогиях в соотношении семантических и звуковых единиц / Т. В. Булыгина // Вопросы языкознания. - 1967. - № 5. - С. 76-86.

6. Гинзбург Р. С. Реферативная соотнесенность слова и сочетаемость / Р. С. Гинзбург // Проблемы сочетаемости слов : [сб. науч. тр.] / МГПИИЯ им. М. Тореза]. - М. : МГПИИЯ, 1979. - Вып. 145. - С. 79-92.

7. Долинин К. А. Имплицитное содержание высказывания / К. А. Долинин // Вопросы языкознания. - 1983. - № 6. - С. 37-47.

8. Ельмслев Л. Пролегомены к теории языка : [пер. с англ.] / Л. Ельмслев // Новое в лингвистике. - М. : Прогресс, 1960. - Вып. І. - С. 264-389.

9. Зиндер Л. Р. Общая фонетика : [учебное пособие] / Л. Р. Зиндер. - [2-е изд., перераб. и доп.]. - М. : Высшая школа, 1979. - 312 с.

10. Кондратов А. Звуки и знаки / А. Кондратов. - [2-е изд., перераб.]. - М. : Знание, 1978. $-208 \mathrm{c}$.

11. Коптілов В. В. Фоностилістика / В.В.Коптілов // Сучасна українська літературна мова. Стилістика : [підручник] / за заг. ред. акад. І. К. Білодіда. - К. : Наукова думка, 1973. - С. 211-243.

12. Кочерган М. П. Форма і зміст у мові / М. П. Кочерган // Українська мова : [енциклопедія] / В. М. Русанівський, О. О. Тараненко, М. П. Зяблюк та ін. - К. : Вид-во «Українська енциклопедія» ім. М. П. Бажана, 2000. - С. 704-705.

13. Курилович Е. Очерки по лингвистике : [сб. статей] / Е. Курилович. - М. : Иностранная л-ра, 1962. - 452 с.

14. Макаев Э. А. К вопросу об изоморфизме // Э. А. Макаев // Вопросы языкознания. - 1961. - № 5. - С. 51-56.

15. Радзієвська Т. В. Ціннісні орієнтації у семантиці мовних одиниць / Т. В. Радзієвська // Мовознавство. - 1996. - №1. - С. 14-19.

16. Селіванова О. О. Сучасна лінгвістика : [термінологічна енциклопедія] / О. О. Селіванова. - К. - Полтава : Довкілля, 2006. - 716 с.

17. Семчинський С. В. Загальне мовознавство : [підручник] / С. В. Семчинський. ๑ Л. Ф. Українець, 2015. 
К. : Вища шк., 1988. - 328 с.

18. Сильман Т. И. Заметки о лирике (мысль - образ - эмоция - звук) /

Т. И. Сильман // Филологические науки. - 1974. - №5. - С. 13-24.

19. Шаховский В. И. Эмотивный компонент значения и методы его описания /

В. И. Шаховский. - Волгоград : Изд-во ВГПИ, 1983. - 96 с.

Стаття надійшла до редакиії 28.07.2015 p. 